\title{
Phytochemical Screening and In-Vitro Antioxidant Activities of Various Extracts of Helichrysum petiolare Hilliard \& B.L. Burtt used for the Treatment of Diabetes Mellitus in the Eastern Cape Province of South Africa
}

\author{
Adebowale Emmanuel Aladejana ${ }^{1,2}$, Graeme Bradley $^{1}$ and Anthony Jide Afolayan ${ }^{2, *}$ \\ ${ }^{1}$ Department of Biochemistry and Microbiology, University of Fort Hare, Alice, 5700, Eastern Cape, South \\ Africa \\ ${ }^{2}$ Medicinal Plants and Economic Development (MPED) Research Centre, University of Fort Hare, Alice, 5700, \\ Eastern Cape, South Africa
}

\begin{abstract}
The phytochemical contents of the acetone, ethanol, and boiled and cold aqueous whole-plant extracts of Helichrysum petiolare were determined using standard phytochemical reaction methods. ABTS, DPPH, NO and TAC assays were used to evaluate their antioxidant properties. This study reported the highest total phenolic content $(212,963 \mathrm{mg} / \mathrm{g})$ in the boiled aqueous extract, while the ethanol had the highest flavonoid $(172.393 \mathrm{mg} / \mathrm{g})$ and proanthocyanidin contents $(65.855 \mathrm{mg} / \mathrm{g})$. Alkaloids, flavonols, and saponin were highest in the acetone extract, while the cold aqueous extract had the lowest phytochemical content. Among the extracts, the boiled aqueous extract had the highest DPPH ${ }^{++}\left(\mathrm{IC}_{50} 0.02 \mathrm{mg} / \mathrm{mL}\right)$ and $\mathrm{ABTS}^{++}\left(\mathrm{IC}_{50} 0.07\right)$ inhibition capacities, while the ethanol extract exhibited the highest NO Inhibition $\left(\mathrm{IC}_{50} 0.41 \mathrm{mg} / \mathrm{mL}\right)$ and TAC $\left(\mathrm{IC}_{50} 0.19 \mathrm{mg} / \mathrm{mL}\right)$. These findings justify the use of $H$. petiolare in traditional medicine and further recommend the ethanol and boiled aqueous extracts of the plant as more effective extracts for medicinal treatment.
\end{abstract}

Keywords: ABTS, Alkaloid, DPPH, Helichrysum petiolare, Proanthocyanidin, Saponin.

\section{INTRODUCTION}

Phytochemicals are synthesized by plants through primary or secondary metabolism [1] and play several vital roles in plants, which include defence against predators, competitors or pathogens, plant growth, etc. $[2,3]$. Some phytochemicals are toxic to humans (phytotoxins) [4]; these include sanguinarine which at low doses can cause cancer [5]. Some have antinutrient properties and limit the absorption of nutrients [6], while others, like flavonoids and polyphenols, might be pro-oxidants when ingested in high amounts [7]. Roughly 10,000 different phytochemicals have been identified, while many are still unknown. A few phytochemicals such as terpenes, flavonoids, isoflavones indoles, phytic acid, glucosinolates, polyphenols, isothiocyanatesols, and carotenoids, however, have antioxidative and medicinal benefits.

Antioxidants are compounds that inhibit free radicalinduced oxidation. Some antioxidants like ascorbic acid (vitamin C) or thiols terminate the chain reactions in free radical generation/oxidation. Complex systems of overlapping antioxidants are maintained by plants

*Address correspondence to this author at the Medicinal Plants and Economic Development (MPED) Research Centre, University of Fort Hare, Alice, 5700, Eastern Cape, South Africa; Tel: +27 40602 2323; Mob: +27 82202 2167;

E-mail: aafolayan@ufh.ac.za

ISSN: 2223-3806 / E-ISSN: 1927-5951/20 and animals in their quest to balance the oxidative state. In animals, these antioxidants are either produced internally e.g. glutathione, superoxide dismutase and catalase or derived from the diet e.g. vitamins $E$ and $C$ [8]. Antioxidants operate at different levels by scavenging free radicals, inhibiting the formation of ROS, or increasing the capabilities of antioxidant enzymes. Endothelial dysfunction in type 2 diabetes mellitus (T2DM), for example, could be potentially improved by supplementation with antioxidants and/or factors essential to nitric oxide (NO) production by re-coupling mitochondrial function and endothelial nitric oxide synthase (eNOS), as well as decreasing vascular $\mathrm{NAD}(\mathrm{P}) \mathrm{H}$ oxidase activity [8].

Oxidative stress is any alteration in the balance of the body's antioxidants and free radicals in favour of the free radicals, caused by factors like drug actions, addiction, toxicity, ageing and inflammation [9]. It is in general, defined as the increased systemic manifestation or/and inadequate removal of reactive oxygen species (ROS), reactive nitrogen species (RNS) and reactive chlorine species (RCS) [10]. In a metabolic disease like diabetes particularly type 2 diabetes, oxidative stress is believed to play a key role in vascular complication development [11]. Tissues are made susceptible to oxidative stress as a result of variation in the levels of antioxidant enzymes, which leads to the development of diabetic complications [12]. (C) 2020 SET Publisher 
The concept that diets high in fruits and vegetables reduce the risk of coronary heart disease (CHD), hypertension, stroke and other diseases evidenced by dose-response relationships has been supported by critical reviews of studies available in the literature [13]. The critical role played by phytochemicals in relieving the body of oxidative stress and reducing the risk of several diseases such as cancer and inflammatory conditions have also been confirmed by several research groups [14]. Recent studies, for example, has cited various effects of phytochemical consumption on reduction in stroke risk [15], cancer prevention [16], and type 2 diabetes prevention [17]. Mechanisms of action proposed for these findings include inhibition of lipid-lowering effects, anti-inflammatory activity, lipid oxidation, antioxidant activity, anti-proliferative or apoptotic cell death activity, as well as hypoglycaemicand insulin-lowering effects [17].

Plants have copious amounts of natural antioxidants and phytochemicals like polyphenol and various antioxidative compounds which adsorb and neutralize reactive oxygen species [18].

Asteraceae families are well-known sources of antioxidants and antimicrobial agents [19]. The leaves and roots extracts of Helichrysum petiolare have been reported to possess antihypertensive and anti-diabetic effects [20]. Previous studies on several other member plants of the Asteraceae family have reported high antioxidant and free radical scavenging abilities [21]. The objective of this study, therefore, is to evaluate the phytochemical contents and antioxidant capacities of the various extracts of the whole plant of $H$. petiolare a less studied member of the Asteraceae family.

\section{MATERIALS AND METHODS}

\subsection{Sample Collection}

The whole plant of $H$. petiolare was purchased from Rastafarians who collected it from Hogsback, in Raymond Mhlaba Municipality of Eastern Cape. The plant collected was identified and authenticated by Professor C.N. Cupido of the Department of Botany, University of Fort Hare, Alice, and a voucher was submitted at the Giffen herbarium, University of Fort Hare, Alice Campus, Eastern Cape, South Africa.

\subsection{Preparation of Extracts}

The whole plant was washed, cleaned and ovendried at $40{ }^{\circ} \mathrm{C}$. The dried sample was pulverized using an electrical blender and sieved ( $20 \mu$ mesh). A portion
$(200 \mathrm{~g})$ of the sample was then soaked individually in 1 $L$ of ethanol, acetone, and water (for cold aqueous extracts) and shaken on an orbital shaker for $24 \mathrm{~h}$, while another portion was boiled in $1 \mathrm{~L}$ of water (for boiled aqueous extract) for 15 minutes. The solution obtained was then filtered using a Buchner funnel and Whatman No. 1 filter papers and concentrated at $78^{\circ} \mathrm{C}$ and $57{ }^{\circ} \mathrm{C}$ respectively for ethanol and acetone extracts using a Rotary vacuum evaporator (Scietek, MODEL: RE 300), while the aqueous extracts were concentrated using a freeze drier. The concentrated extracts were stored at $4{ }^{\circ} \mathrm{C}$ in the refrigerator until needed for use [22].

\subsection{Phytochemical content analysis of the ethanol, acetone and aqueous plant extracts}

\section{i. Total Phenols Determination}

The modified Folin-Ciocalteu method as described by Bouaziz-Ketata et al. (2015) was used to determine the extracts' total phenolic content. $5 \mathrm{~mL}$ of FolinCiocalteu reagent in distilled water $(1: 10 \mathrm{v} / \mathrm{v})$ and $4 \mathrm{~mL}$ $(75 \mathrm{~g} / \mathrm{L})$ of sodium carbonate were mixed with an aliquot of $0.5 \mathrm{~mL}$ of each extract $(1 \mathrm{mg} / \mathrm{mL})$. The resulting mixtures were then vortexed for $15 \mathrm{~s}$ and left to stand for $30 \mathrm{~min}$ at $40{ }^{\circ} \mathrm{C}$ to develop colour. Absorbance was then measured at $765 \mathrm{~nm}$ wavelength using the AJI-C03 UV-VIS spectrophotometer. The results were expressed as $\mathrm{mg} / \mathrm{g}$ tannic acid equivalent using the equation based on the calibration curve: $Y=$ $4.7783 x+0.0729 ; \quad R^{2}=0.9986$, where $x$ is the absorbance and $\mathrm{Y}$ is the tannic acid equivalent.

\section{ii. Determination of Total Flavonoids}

Determination of the flavonoid content was done using the method described by Sowunmi and Afolayan, (2015). $0.5 \mathrm{~mL}$ of $2 \% \mathrm{AlCl}_{3}$ was briefly prepared in ethanol and then added to $0.5 \mathrm{~mL}$ of the extracts. The mixture obtained was left to stand for $60 \mathrm{~min}$ at room temperature and the absorbance was measured at 420 $\mathrm{nm}$. The extracts were evaluated at a final concentration of $0.1 \mathrm{mg} / \mathrm{mL}$ and the results were calculated as quercetin equivalent $(\mathrm{mg} / \mathrm{g})$ using the equation based on the calibration curve: $Y=6.5583 \mathrm{x}+$ $0.0674 ; R^{2}=0.9995$; where $x$ is the absorbance and $y$ is the quercetin equivalent.

\section{iii. Determination of Total Flavonols}

The flavonol content was determined using the method described by Sowunmi and Afolayan, (2015). 2 $\mathrm{mL}$ of each plant extract was mixed with $2 \mathrm{~mL}$ of $2 \%$ $\mathrm{AlCl}_{3}$ prepared in ethanol, $3 \mathrm{~mL}$ of sodium acetate solution $(50 \mathrm{~g} / \mathrm{L})$ was then added. The mixture was 
incubated for $150 \mathrm{~min}$ at $20{ }^{\circ} \mathrm{C}$. Absorbance was measured at $440 \mathrm{~nm}$. The total flavonol content was calculated as quercetin $(\mathrm{mg} / \mathrm{g})$ equivalent, using the following equation based on the calibration curve: $Y=13.537 x+0.0195 ; R^{2}=0.9986$, where $x$ is the absorbance and $Y$ is the quercetin equivalent.

\section{iv. Determination of Proanthocyanidin}

Determination of the total proanthocyanidin was done using the method described by Sowunmi and Afolayan, (2015). $3 \mathrm{~mL}$ of $4 \%$ vanillin/methanol solution and $1.5 \mathrm{~mL} \mathrm{HCl}$ was mixed with a volume of $0.5 \mathrm{~mL}$ of the extract solution. The resulting mixture was vortexed, left to stand for $15 \mathrm{~min}$ at room temperature, and the absorbance was read at $500 \mathrm{~nm}$. The total proanthocyanidin content was expressed as catechin equivalents $(\mathrm{mg} / \mathrm{g})$ using the calibration curve equation: $Y=2.9833 x+0.0192 ; R^{2}=0.9916$, where $x$ is the absorbance and $\mathrm{Y}$ is the catechin equivalent.

\section{v. Determination of Saponins}

This assay was carried out according to the method described by Sowunmi and Afolayan, (2015). Briefly, $200 \mathrm{~mL}$ of $20 \%$ was mixed on a shaker with $20 \mathrm{~g}$ of the plant for $30 \mathrm{~min}$, after which the mixture obtained was heated and stirred in a water bath at $55^{\circ} \mathrm{C}$ for $240 \mathrm{~min}$. The mixture was filtered and the residue obtained was re-extracted as described above. The two extracts were combined and further heated on a water bath at $90{ }^{\circ} \mathrm{C}$ to reduce the volume to $40 \mathrm{~mL}$, after which it was transferred into a $250 \mathrm{~mL}$ separating funnel and extracted twice using $20 \mathrm{~mL}$ diethyl ether. The ether layer was discarded, retaining the aqueous layer to which $60 \mathrm{~mL}$ of $\mathrm{n}$-butanol was added. The $\mathrm{n}$-butanol extracts were then washed twice using $10 \mathrm{~mL}$ of $5 \%$ brine solution. This final solution was then concentrated at $87{ }^{\circ} \mathrm{C}$ on a water bath, then oven-dried to dryness at $40{ }^{\circ} \mathrm{C}$. The percentage of saponin content was calculated using the formula:

$\%$ saponin $=\frac{\text { final weight of the sample }}{\text { initial weight of the sample }} \times 100$

\section{vi. Determination of Alkaloids}

Alkaloid content was determined according to the method described by Sowunmi and Afolayan, (2015). Briefly, $200 \mathrm{~mL}$ of $10 \%$ ethanolic acetic acid was mixed with $5 \mathrm{~g}$ of the plant extract, covered and left to stand for $240 \mathrm{~min}$. The mixture was filtered, heated in a water bath at $60{ }^{\circ} \mathrm{C}$ to one-quarter of its original volume. Concentrated ammonia solution was added to the mixture to trigger precipitation, and then continued until the precipitation stops. The whole solution was then left for a while to settle, filtered and the precipitate washed with dilute ammonium hydroxide. The residue obtained was dried and weighed and the alkaloid content was calculated using this formula:

$\%$ alkaloid $=\frac{\text { final weight of the sample }}{\text { initial weight of the sample }} \times 100$

All the experiments were done in triplicates.

\subsection{Determination of the Antioxidant Potentials of H. petiolare}

The antioxidant activities of $H$. petiolare were determined by evaluating the percentage inhibition of free radicals.

\section{i. Total Antioxidant Capacity (TAC)}

The TAC of the extracts was determined using the method described by Falode et al. (2018). $1 \mathrm{~mL}$ of the extract or standard $(0.5-1.0 \mathrm{mg} / \mathrm{mL})$ solution was pipetted into test tubes at varying concentrations. Thereafter, $3 \mathrm{~mL}$ of phosphomolybdate reagent $(28 \mathrm{mM}$ sodium phosphate, $4 \mathrm{mM}$ ammonium molybdate, and $0.6 \mathrm{M}$ sulphuric acid) was added to each of the test tubes (The blank solution contained $4 \mathrm{~mL}$ reagent solution only). The test tubes were capped and incubated in a boiling water bath at $95{ }^{\circ} \mathrm{C}$ for $150 \mathrm{~min}$. The samples were left to cool to room temperature, and the absorbance of each solution was measured at 695 $\mathrm{nm}$ against blank in a spectrophotometer. The antioxidant capacity was expressed as the rutin equivalent.

\section{ii. Determination of NO Radical (NO) Scavenging Activity}

Determination of the $\mathrm{NO}^{\circ}$ scavenging activity of the extract was done using the method of Falode et al. (2018). $0.5 \mathrm{~mL}$ of the extract and standards of varying concentrations $(0.2-1.0 \mathrm{mg} / \mathrm{mL})$ was added to $2 \mathrm{~mL}$ of $10 \mathrm{mM}$ sodium nitroprusside prepared in $0.5 \mathrm{mM}$ phosphate buffer saline $(\mathrm{pH} 7.4)$ and incubated for 2.5 $\mathrm{h}$ at $25{ }^{\circ} \mathrm{C}$. $1 \mathrm{~mL}$ was then taken from the incubated mixture and combined with $1 \mathrm{~mL}$ of Griess reagent (equal volume of $0.33 \%$ Sulphanilic reagent (sulfanilic acid dissolved in $20 \%$ glacial acetic acid) and $0.1 \%(\mathrm{w} / \mathrm{v}) 1$-naphthylenediaminedichloride (prepared in distilled water)), this was then incubated at room temperature for $30 \mathrm{~min}$. The absorbance was measured at $540 \mathrm{~nm}$ and percentage $\mathrm{NO}^{\circ}$ inhibition by the extract calculated using the equation:

$N O \bullet$ scavenging activity $(\%)=\left(\frac{A b s \text { control }- \text { Abs sample }}{A b s \text { control }}\right) \times 100$ 
Where $\mathrm{Abs}_{\text {control }}$ was the absorbance of $\mathrm{NO}^{\circ} ; \mathrm{Abs}_{\text {sample }}$ was the absorbance of $\mathrm{NO}^{\circ}+$ sample or standard.

\section{iii. Determination of Diphenyl-1-Picrylhydrazyl (DPPH) Radical Scavenging Activity}

The method described by Falode et al. (2018) was used to determine the scavenging activity of DPPH free radical $\left(\mathrm{DPPH}^{\circ+}\right)$ of the extract. A stock solution of $0.135 \mathrm{mM}$ DPPH was prepared in methanol. $0.1 \mathrm{~mL}$ of the extract and standards of varying concentrations $(0.005-0.08 \mathrm{mg} / \mathrm{mL})$ was added to $1 \mathrm{ml}$ of the stock solution. The reaction mixture was then vortexed thoroughly and left in the dark at room temperature for $30 \mathrm{~min}$. The absorbance of the mixture was measured at $517 \mathrm{~nm}$ using the spectrophotometer. The ability of the plant extract to scavenge $\mathrm{DPPH}^{\cdot+}$ was calculated from the equation:

$D P P H^{\cdot+}$ scavenging activity $=\left(\frac{\text { Abs control }- \text { Abs sample }}{A b s \text { control }}\right) \times 100$

Where $\mathrm{Abs}_{\text {control }}$ is the absorbance of $\mathrm{DPPH}^{\circ+}+$ methanol; $\mathrm{Abs}_{\text {sample }}$ is the absorbance of $\mathrm{DPPH}^{\circ+}+$ sample/standards.

\section{iv. Determination of ABTS Radical $\left(A B T S^{\circ+}\right)$ Scavenging Activity}

The ability of the plant extracts to scavenge-2, 2'azino-bis (3-ethylbenzothiazoline-6-sulphonic acid) (ABTS) radical was determined using the methods of Ahmed et al. (2015). The working solution was prepared by mixing $2.4 \mathrm{mM}$ of potassium persulfate and $7 \mathrm{mM}$ of ABTS in the ratio 1:1 in distilled water. The mixture was left to react in the dark for $12 \mathrm{~h}$ at room temperature. After $12 \mathrm{~h}, 3 \mathrm{~mL}$ of the working solution was further diluted with $150 \mathrm{~mL}$ methanol to obtain an absorbance of $0.706 \pm 0.002$ units at $734 \mathrm{~nm}$ using a spectrophotometer. This was adjusted by mixing of ABTS previously prepared using the method outlined above. $1 \mathrm{~mL}$ of the working solution was then added to the extracts at varying concentrations $(0.2$ $1.0 \mathrm{mg} / \mathrm{mL}$ ) and allowed to react in the dark. The absorbance was measured at $734 \mathrm{~nm}$ after $7 \mathrm{~min}$. The $\mathrm{ABTS}^{\circ+}$ scavenging capacity was compared with BHT and ascorbic acid. The percentage of inhibition was calculated as follows:

ABTS $^{*+}$ scavenging activity $=\left(1-\frac{\text { Abs sample }}{\text { Abs control }}\right) \times 100$

Where $\mathrm{Abs}_{\text {sample }}$ is the absorbance of $\mathrm{ABTS}^{++}+$sample (extract or standard)
Abs control is the absorbance of $\mathrm{ABTS}^{\circ+}+$ methanol.

\section{RESULTS}

The phytochemical content of whole plant extracts of $H$. petiolare is shown in Table 1 . Based on the results obtained, the boiled aqueous extract $(212,963 \pm$ $0,260 \mathrm{mg} / \mathrm{g}$ ) of $H$. petiolare had the highest overall phenolic content compared to other extracts.

The ethanol extract also had a very high phenolic content, with the highest levels of flavonoids (172.39 \pm $5.34 \mathrm{mg} / \mathrm{g}$ ) and proanthocyanidins (65.86 $\pm 1.73 \mathrm{mg} / \mathrm{g})$ among the extracts. The acetone extract also had flavonol $(143.87+0.55 \mathrm{mg} / \mathrm{g})$, saponin $(263.73+1.60$ $\mathrm{mg} / \mathrm{g})$ and alkaloid $(28+0.99 \mathrm{mg} / \mathrm{g})$ contents that were significantly higher than those of the other extracts.

The In vitro antioxidant test of the whole plant extracts of $H$. petiolare demonstrated important and concentration-dependent total antioxidant potential (TAC) relative to the standards (i.e. ascorbic acid and $\mathrm{BHT}$ ) (Figure 1).

Table 2 displays the $I_{50}$ of the extracts and standards against DPPH, ABTS, and NO radicals. According to this study, the four plant extracts had dose-dependent $\mathrm{DPPH}^{\circ+}$ scavenging activities (Figure 2), but their activities were relatively low compared to all the standards at concentrations above $0.02 \mathrm{mg} / \mathrm{mL}$, but they all had $\mathrm{DPPH}^{\text {*+ }}$ scavenging abilities that were greater than or equal to ascorbate at concentrations below $0.02 \mathrm{mg} / \mathrm{mL}$. The result also showed significant dose-dependent $\mathrm{ABTS}^{\text {++ }}$ scavenging activity across all extracts (Figure 3 ), activity was much higher than that found in $\mathrm{DPPH}^{\circ+}$, and activity was higher for acetone $\left(\mathrm{IC}_{50} 0.02 \mathrm{mg} / \mathrm{ml}\right)$ and boiled aqueous extracts $\left(\mathrm{IC}_{50}\right.$ $0.02 \mathrm{mg} / \mathrm{ml}$ ) at concentrations above $0.01 \mathrm{mg} / \mathrm{mL}$.

All plant extracts showed elevated inhibition of $\mathrm{NO}^{\circ}$ greater than $80 \%$. The activities of the extracts were extremely competitive with those of the standards. However, the activities of the extracts were non-dosedependent, except for acetone and ethanol extracts, which showed a slight decrease in activity with an increase in concentration.

\section{DISCUSSION}

Analysis of acetone, ethanol, cold and boiled aqueous extracts from the entire plant of $H$. petiolare revealed the presence of saponins, alkaloids, flavonoids, flavonols and proanthocyanidins (Table 1). Proanthocyanidins are condensed tannins with varying pharmacological properties [27]. They possess a broad 
Table 1: Phytochemical Constituents of $\boldsymbol{H}$. petiolare Whole-Plant Extracts

\begin{tabular}{|c|c|c|c|c|}
\hline Phytochemicals & Boiled Aqueous & Cold Aqueous & Acetone & Ethanol \\
\hline Total Phenols & $212.96 \pm 0.26^{a}$ & $147.04 \pm 0.26^{d}$ & $204.80 \pm 1.30^{b}$ & $187.85 \pm 0.78^{c}$ \\
\hline Flavonoids & $21.67 \pm 0.95^{c}$ & $11.45 \pm 0.19^{d}$ & $102.86 \pm 3.24^{b}$ & $172.39 \pm 5.34^{a}$ \\
\hline Proanthocyanidins & $2.28 \pm 0.83^{c}$ & $2.06 \pm 0.48^{c}$ & $60.27 \pm 0.83^{b}$ & $65.86 \pm 1.73^{a}$ \\
\hline Flavonols & $11.93 \pm 0.18^{d}$ & $15.06 \pm 0.11^{c}$ & $143.87 \pm 0.55^{a}$ & $107.78 \pm 0.09^{b}$ \\
\hline Saponin & $206.07 \pm 0.29^{c}$ & $71.8 \pm 0.50^{d}$ & $263.73 \pm 1.60^{a}$ & $211.67 \pm 0.76^{b}$ \\
\hline Alkaloids & $26.07 \pm 1.25^{b}$ & $24.13 \pm 1.52^{c}$ & $28 \pm 0.99^{a}$ & $25.93 \pm 0.29^{b}$ \\
\hline
\end{tabular}

Values along the same row followed by different superscript are significantly different $(P<0.05)$.

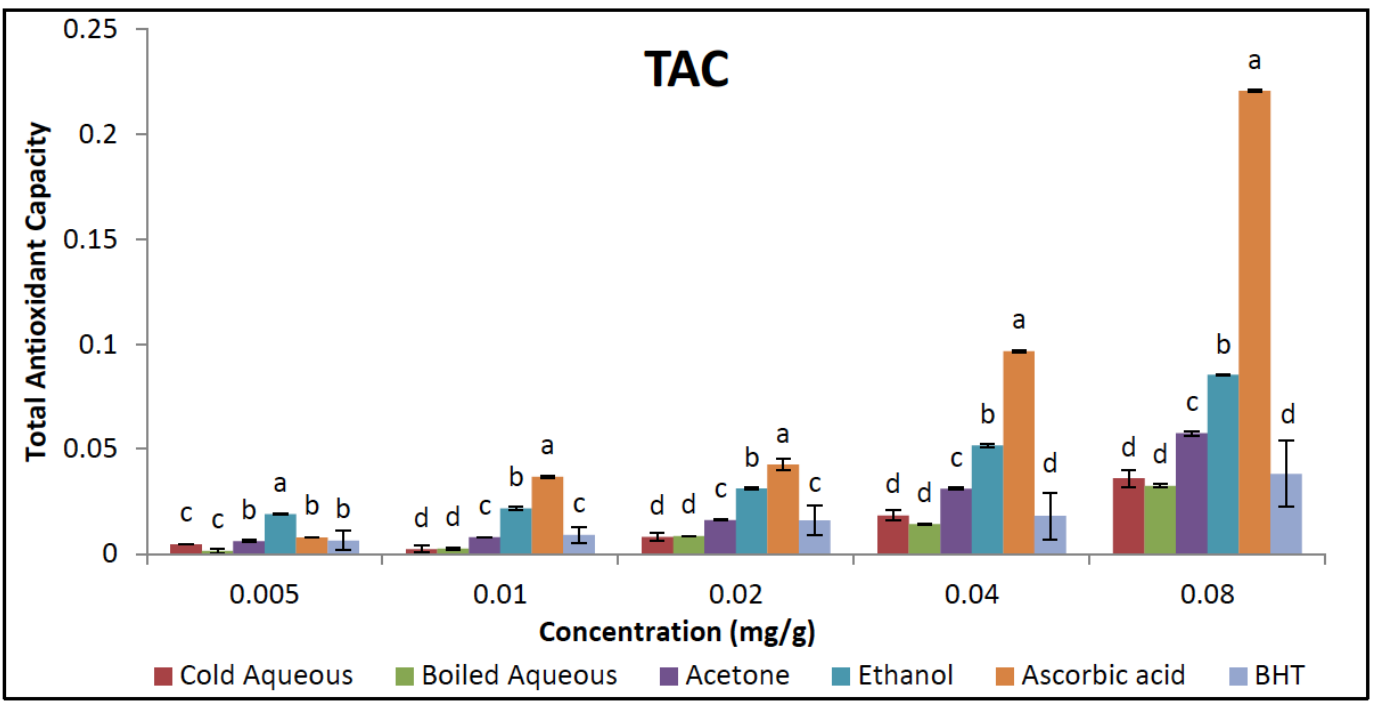

Figure 1: Total antioxidant capacities of ascorbic acid, BHT, cold and boiled aqueous, acetone and ethanol whole plant extracts of $H$. petiolare. Data are presented as means $\pm S D$ of three replicates. Points with the same alphabet within the same concentration are not significantly different.

Table 2: Scavenging Activities of Aqueous (Cold and Boiled), Acetone and Ethanol Whole Plant Extracts of $H$. petiolare

\begin{tabular}{|c|c|c|c|c|c|c|c|c|}
\hline \multirow{2}{*}{$\begin{array}{l}\text { Activity } \\
\text { Samples } \\
\end{array}$} & \multicolumn{2}{|c|}{ A } & \multicolumn{2}{|c|}{ B } & \multicolumn{2}{|c|}{ C } & \multicolumn{2}{|c|}{ D } \\
\hline & $\mathrm{IC}_{50}^{\mathrm{a}}$ & $\mathbf{R}^{2 b}$ & $\mathrm{IC}_{50}{ }^{\mathrm{a}}$ & $\mathbf{R}^{2 b}$ & $\mathrm{IC}_{50}^{\mathrm{a}}$ & $\mathbf{R}^{2 b}$ & $\mathrm{IC}_{50}{ }^{\mathrm{a}}$ & $\mathbf{R}^{2 b}$ \\
\hline Cold aqueous extract & 0.03 & 89.99 & 0.12 & 99.92 & 0.89 & 94.04 & 0.41 & 98.5 \\
\hline Boiled aqueous extract & 0.02 & 72.47 & 0.07 & 99.8 & 2.74 & 87.23 & 0.45 & 99.34 \\
\hline Acetone extract & 0.02 & 67 & 0.19 & 99.94 & 0.59 & 99.46 & 0.26 & 99.85 \\
\hline Gallic acid & 0.55 & 78.04 & - & - & - & - & - & - \\
\hline Ascorbic acid & - & - & 0.03 & 79.5 & 0.52 & 93.39 & 0.04 & 99.96 \\
\hline $\mathrm{BHT}$ & 0.04 & 91.65 & 0.006 & 61.68 & 3.93 & 91.83 & 0.61 & 95.23 \\
\hline
\end{tabular}

The letters represent; $\mathbf{A}=\mathrm{ABTS} \cdot+$ scavenging activity; $\mathbf{B}=\mathrm{DPPH} \cdot+$ scavenging activity; $\mathbf{C}=\mathrm{NO} \cdot$ scavenging activity; $\mathbf{D}=\mathrm{TAC}$; : $\mathrm{IC}_{50}$ is defined as the concentration $(\mathrm{mg} / \mathrm{mL})$ sufficient to obtain $50 \%$ of a maximum scavenging capacity; $\mathbf{b}$ : coefficient of determination; values obtained from regression lines with $95 \%$ confidence level and -: Values not determined. 


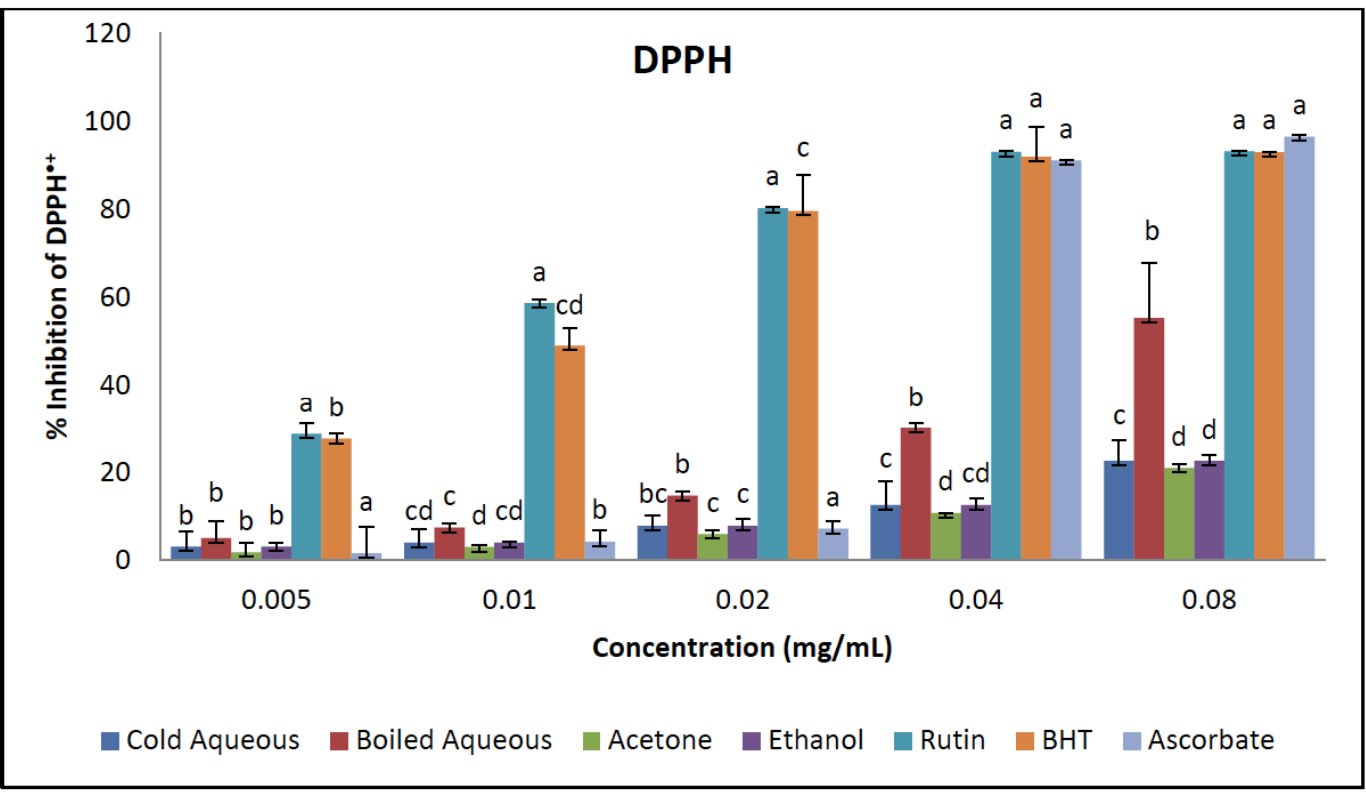

Figure 2: $\mathrm{DPPH}^{++}$scavenging activities of $\mathrm{BHT}$, rutin, ascorbate, ethanol, acetone, boiled aqueous and cold aqueous whole plant extracts of $H$. petiolare. Data are presented as means \pm SD of three replicates. Bar graphs with the same letter superscripts within the same concentration are not significantly different.

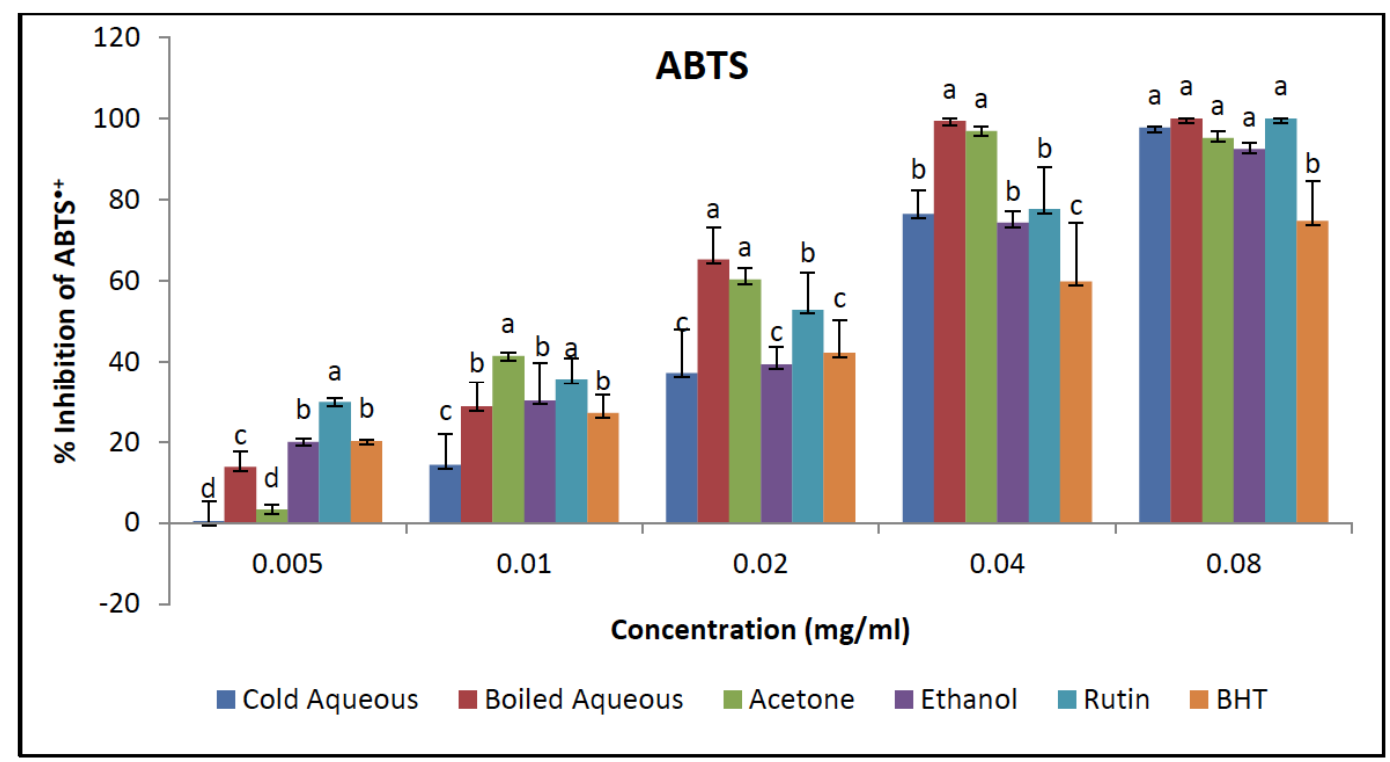

Figure 3: $\mathrm{ABTS}^{\circ+}$ scavenging activities of BHT, rutin, ascorbate, ethanol, acetone, boiled aqueous and cold aqueous whole plant extracts of $H$. petiolare. Data are presented as means \pm SD of three replicates. Bar graphs with the same letter superscripts within the same concentration are not significantly different.

variety of beneficial properties including anti-tumour, anti-bacterial, immunostimulating, anti-allergic, antioxidant, anti-viral, anti-carcinogenic, anti-inflammatory and vasodilatory properties [27].

Studies have shown that eating proanthocyanidinrich plants/fruits helps protect the body from sun damage, improve vision, improve joint, artery, and body tissue (e.g heart) flexibility, and improve blood supply by improving the veins, capillaries, and arteries [28]. They can also prevent the accumulation of platelets, lipid peroxidation and hyperpermeability of capillaries $[28,29]$.

Flavonoids also have a broad variety of biological functions, including antioxidative, analgesic, antiallergic, antiangionic, antihypertensive, anticancer, antidiabetic, antimicrobial, and antiinflammatory effects [30]. Their antioxidant effects are also expressed by the inactivation of reactive oxygen species (ROS), thus counteracting plasma low-density lipoprotein (LDL) oxidation and thereby improving blood vessel 
endothelium inflammation [31]. Latest findings have demonstrated the health effects of dietary flavonoids, as there was a strong association between their ingestion and lower risk of hypertension and cardiovascular mortality [32]. The very high content of flavonoids and proanthocyanidins in the ethanol extract may be attributable to the high extraction yield of the solvent and explain why the extract has the maximum NO ${ }^{\circ}$ scavenging potential and TAC.

This also confirms the observations of Akinrinde et al. (2018) and further supports the utility of $H$. petiolare ethanol extract in the treatment and prevention of hypertension, cancer, fire injuries and other forms of injuries, allergies, common diseases, obesity, insulin resistance, coronary heart disease and diabetes. These findings also illustrate why in conventional herbal therapy, boiled aqueous extracts and ethanol herbal concoctions are preferable, as high phenolic content has been shown to associate strongly with high antioxidant activity by some writers [34], and other studies have put more emphasis on the main role of phenolic compounds as free radical scavengers [35].

Three of the main subclasses of flavonoids (e.g. quercetin, kaempferol, and myricetin) are flavonoids, flavonols, and flavanols or catechins [36], which are mildly ingested in an intestine with normal bacterial flora and are heavily metabolized in humans [37]. It has also been stated that flavonol is a flavonoid with substantially strong antioxidant properties. In previous research, increased activity of erythrocyte superoxide dismutase (an antioxidant enzyme in red blood cells) was correlated with the intake of plants rich in flavonol. Also, flavonol induces an improvement in plasma antioxidant potential (the ability to scavenge free radicals), a decrease in lymphocyte DNA damage and a decrease in urinary 8-hydroxy-2'-deoxyguanosine (a predictor of oxidative damage) [38]. Flavonol has also been reported to possess anticancer, anticoronary heart disease, and anti-diabetic properties in many studies $[39,40]$.

This explains why the highest TAC was found in the ethanol extract with very high flavonoid and flavonol content (Figure 1). In general, $H$. petiolare acetone and ethanol extracts may also be beneficial in preventing and treating cancer, coronary artery disease and diabetes.

The acetone and ethanol extracts in this study had the highest concentration of saponin, followed by the boiled aqueous extract. Saponins are heat stable, amphiphilic, glycosidic compounds that are naturally found in a wide range of plant foods [41]. A previous study found that saponins increase cardiovascular health due to their ability to lower levels of blood cholesterol and body fat, cholesterol absorption was also said to be hindered by the intake of plants rich in saponins by saponins binding with bile salts [42].

In clinical trials, ginger and ginseng's saponins were shown to decrease total and LDL (bad) cholesterol without altering the levels of HDL (good) cholesterol [42]. Therefore in the prevention and treatment of hypercholesterolemia, hyperlipidemia, high blood pressure, atherosclerosis and cardiovascular diseases (CVDs), acetone, ethanol and boiled aqueous extracts of $H$. petiolare might be very useful.

Despite reports from several authors that phenolic compounds are unstable and lose their antioxidant

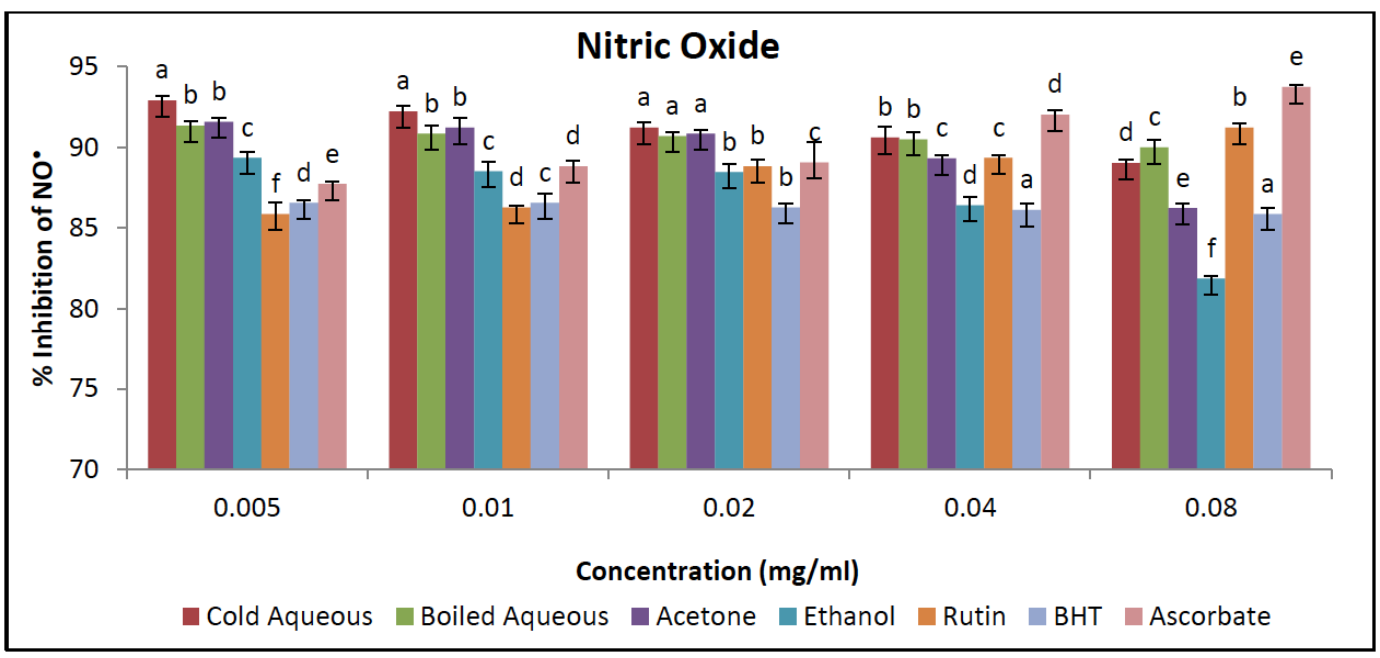

Figure 4: $\mathrm{NO}^{\circ}$ scavenging activities of $\mathrm{BHT}$, rutin, ascorbate, ethanol, acetone, boiled aqueous and cold aqueous whole plant extracts of $H$. petiolare. Data are presented as means \pm SD of three replicates. Bar graphs with the same letter superscripts within the same concentration are not significantly different. 
capacity once they have been heated [43], the boiled aqueous extract exhibited the highest levels of $\mathrm{DPPH}^{\circ+}$ and $\mathrm{ABTS}^{\circ+}$ scavenging activity (Figures $2 \& 3$ ), this may be due to the high extractive capacity of the decoction method and the presence of heat-stable, viable antioxidant compounds. However, the TAC and NO scavenging capacity of the boiled aqueous extract (Figures 1 \& 4) was the lowest; due to heat instability which may have resulted into loss of antioxidant power of the phenols.

The strong $\mathrm{ABTS}^{*+}$ scavenging potential of all plant extracts compared to rutin and BHT suggests that there were some antioxidant compounds in the plant that can be isolated using water, ethanol and even acetone. Acetone and boiled aqueous extracts exhibited the highest $\mathrm{ABTS}^{\circ+}$ scavenging abilities (Figure 3); these high $\mathrm{ABTS}^{\text {++ }}$ scavenging abilities were possibly due to the high saponin and flavonoid content of the extracts. Phenols of boiled aqueous extracts were believed to have grossly reduced antioxidant properties since the previous study found phenols to be unstable by losing their antioxidant properties at high temperatures [43], saponins, however, are more heat stable and show no decrease in antioxidant properties even at high temperatures [41]. High $\mathrm{ABTS}^{*+}$ scavenging properties of acetone and boiled aqueous extracts, therefore, imply that conditions caused by $\mathrm{ABTS}^{\circ+}$-like free radicals may be treated by traditional healers using the plant's acetone and boiled aqueous extracts. The extracts may also be used in the treatment of inflammation, cardiovascular disease, atherosclerosis and hypercholesterolemia.

These observations were similar to the findings of Al-laith et al. (2019), in which compounds with high $\mathrm{ABTS}^{\circ+}$ scavenging activity reported low $\mathrm{DPPH}^{\circ+}$ scavenging activity.

The results also showed that the four plant extracts used in this study had dose-dependent $\mathrm{DPPH}^{+}$ scavenging activities (Figure 4), but their activities were quite low compared to all standards at concentrations above $0.02 \mathrm{mg} / \mathrm{mL}$, but they all had $\mathrm{DPPH}^{++}$ scavenging potentials greater than or equal to that of ascorbate at concentrations below $0.02 \mathrm{mg} / \mathrm{mL}$. This means that at these low concentrations, the extracts may all be used in replacement of ascorbic acid in cases where there is the scarcity of it. The $\mathrm{NO}^{\circ}$ inhibitory activity of acetone, ethanol, boiled and cold aqueous extracts being higher than that of BHT (Table 2) indicates the comparative ability of the extracts to reduce oxidative damage to certain vital tissues in the body, this is in agreement with several other works done on other species of Helichrysum in which similar phytochemicals and antioxidants are present $[45,46]$.

Since $\mathrm{NO}^{\circ}$ also plays an important role in the pathogenesis of inflammation [47], $H$. petiolare may, therefore, be very effective for treating hyperglycemiainduced inflammation and wound healing.

\section{CONCLUSION}

$H$. petiolare had high phenolic content and strong antioxidant properties. Except for the $\mathrm{DPPH}^{\circ+}$ scavenging assay, the ethanol, acetone and boiled and cold aqueous extracts exhibited activities that were higher than BHT and were comparable to ascorbic acid and rutin. This study revealed some of the plant's antioxidant and medicinal potentials. The plant may be used to address the problems of inflammation, atherosclerosis, insulin resistance and cardiovascular disease because it had strong scavenging abilities for ABTS, DPPH and NO-like radicals, which shows that plant extracts may act against oxidation processes in the human body. This may explain its use as a herbal treatment plant in Eastern Cape to treat conditions such as asthma, coughing, pain, colds, infections, chest problems, and high blood pressure. Finally, in addition to the ethanol extract, this study showed that the boiled aqueous extract had more phytochemical content and antioxidant activity than the cold aqueous extract, which means that ethanol and boiled aqueous herbal extracts may be more potent/effective for herbal treatment than the other extracts.

\section{CONFLICTS OF INTEREST}

The author declares that there are no conflicts of interest regarding the publication of this paper.

\section{ACKNOWLEDGEMENTS}

The authors wish to thank the National Research Foundation (NRF) of South Africa for funding this work.

\section{REFERENCES}

[1] Essack H, Odhav B, Mellem JJ. Screening of traditional South African leafy vegetables for selected anti-nutrient factors before and after processing 2018. https://doi.org/10.1590/1678-457x.20416

[2] Moodley O, Sun Y, Leo F, Makoto S, Pavlov IN, Li Y, et al. Application of Toxigenic Alternaria oxytropis to Soybeans and its Effect on Swainsonine Detection in Different Environments. Bull Environ Contam Toxicol [Internet] 2019; 102(2): 268-74.

https://doi.org/10.1007/s00128-018-2496-0

[3] Ajuru MG, Williams LF, Ajuru G, Harcourt P, Pathology C, Harcourt $P$, et al. Qualitative and Quantitative Phytochemical 
Screening of Some Plants Used in Ethnomedicine in the Niger Delta Region of Nigeria Email address: 2017; 5(5): 198-205. https://doi.org/10.11648/j.jfns.20170505.16 muricata: A comprehensive review on its traditional medicinal uses, phytochemicals, pharmacological activities, mechanisms of action and toxicity. Arab J Chem 2018; 11: 662-91.

https://doi.org/10.1016/j.arabjc.2016.01.004

[5] Croaker A, King GJ, Pyne JH, Anoopkumar-dukie S. Mutation Research-Reviews in Mutation Research Carcinogenic potential of sanguinarine, a phytochemical used in 'therapeutic ' black salve and mouthwash. Mutat Res Mutat Res [Internet] 2017; 774(April): 46-56. https://doi.org/10.1016/j.mrrev.2017.09.001

[6] Mattila PH, Pihlava J, Hellström J, Nurmi M, Eurola M, Mäkinen S, et al. Contents of phytochemicals and antinutritional factors in commercial protein-rich plant products 2018; (October): 213-9.

https://doi.org/10.1093/fqsafe/fyy021

[7] Costa LG, Garrick JM, Roquè PJ, Pellacani C. Mechanisms of Neuroprotection by Quercetin: Counteracting Oxidative Stress and More 2016; 2016. https://doi.org/10.1155/2016/2986796

[8] Zhou H, Wang S, Zhu P, Hu S, Chen Y, Ren J. Empagliflozin rescues diabetic myocardial microvascular injury via AMPKmediated inhibition of mitochondrial fission. Redox Biol [Internet] 2018; 15(December 2017): 335-46. https://doi.org/10.1016//.redox.2017.12.019

[9] Sies H, Berndt C, Jones DP. Oxidative Stress [Internet] 2017. 86: 715-48. https://doi.org/10.1146/annurev-biochem-061516-045037

[10] Levi CA, Ejere VC, Mgbenka BO. Anti-diabetic properties of $\mathrm{N}$-Hexane fruit extract of Dacryodes edulis on AlloxanInduced Diabetic Rats (Rattus novergicus) 2015.

[11] Ighodaro OM, Akinloye OA. First line defence antioxidantssuperoxide dismutase ( SOD ), catalase ( CAT) and glutathione peroxidase ( GPX ): Their fundamental role in the entire antioxidant defence grid. Alexandria J Med [Internet] 2019; 54(4): 287-93.

https://doi.org/10.1016/j.ajme.2017.09.001

[12] Ogboye PO, Onyegeme-Okerenta BM, Monago-Ighorodje C. Proximate Composition, Antioxidant and Hypoglycaemic Potential of Aqueous Extracts of Seeds of Delonix regia on High Fat Diet and Streptozotocin-Induced Diabetes in Female Wistar Rats. Clin Exp Med Sci 2018; 6(1): 33-46. https://doi.org/10.12988/cems.2018.853

[13] Boeing $H$, Bechthold A, Bub A, Ellinger S, Haller D, Kroke A, et al. Critical review: Vegetables and fruit in the prevention of chronic diseases. Eur J Nutr 2012; 51(6): 637-63.

https://doi.org/10.1007/s00394-012-0380-y

[14] Thangapazham RL, Sharad S, Maheshwari RK. Phytochemicals in Wound Healing. Adv Wound Care 2016; 5(5): 230-41.

https://doi.org/10.1089/wound.2013.0505

[15] Kim T, Oh CW, Kwon OK, Hwang G, Kim JE, Kang HS, et al. Stroke prevention by direct revascularization for patients with adult-onset moyamoya disease presenting with ischemia. J Neurosurg 2016; 124(6): 1788-93. https://doi.org/10.3171/2015.6.JNS151105

[16] Kotecha R, Takami A, Espinoza JL. Dietary phytochemicals and cancer chemoprevention: A review of the clinical evidence. Oncotarget 2016; 7(32): 52517-29. https://doi.org/10.18632/oncotarget.9593

[17] Xi P, Liu RH. Whole food approach for type 2 diabetes prevention. Mol Nutr Food Res 2016; 60(8): 1819-36. https://doi.org/10.1002/mnfr.201500963

[18] Kiss AK, Naruszewicz M. Polyphenolic compounds characterization and reactive nitrogen species scavenging capacity of Oenothera paradoxa defatted seed extracts. Food Chem [Internet] 2012; 131(2): 485-92.

https://doi.org/10.1016/j.foodchem.2011.09.011

[19] Khan I, Karim N, Ahmad W, Abdelhalim A, Chebib M. GABAA Receptor Modulation and Anticonvulsant, Anxiolytic , and Antidepressant Activities of Constituents from Artemisia indica Linn. Evidence-Based Complement Altern Med [Internet] 2016; 2016. https://doi.org/10.1155/2016/1215393

[20] Lu M, Han Z, Xu Y, Yao L. Effects of essential oils from Chinese indigenous aromatic plants on mycelial growth and morphogenesis of three phytopathogens. Flavour Fragr J 2013; 28(2): 84-92

https://doi.org/10.1002/ffj.3132

[21] Messina CM, Troia A, Arena R, Manuguerra $S$, loannou $T$, Curcuraci E, et al. Species-Specific Antioxidant Power and Bioactive Properties of the Extracts Obtained from Wild Mediterranean Calendula Spp. (Asteraceae). MDPI [Internet] 2019; 1-13. https://doi.org/10.3390/app9214627

[22] Njagi JM, Ngugi MP, Kibiti CM, Ngeranwa J, Njue W, Gathumbi P, et al. Hypoglycemic Effect of Lippia javanica in Alloxan Induced Diabetic Mice. J Diabetes Metab 2015; 6(11): 30-3 https://doi.org/10.4172/2155-6156.1000624

[23] Bouaziz-Ketata H, Zouari N, Salah H Ben, Rafrafi M, Zegha $\mathrm{N}$. Flavonoid profile and antioxidant activities of methanolic extract of Hyparrhenia hirta (L.) Stapf. Indian J Exp Biol [Internet] 2015; 53(April): 208-15. Available from: http://nopr.niscair.res.in/bitstream/123456789/31234/1/IJEB 53(4) 208-215.pdf

[24] Sowunmi LI, Afolayan AJ. Phytochemical constituents and antioxidant properties of acetone extract of cleome gynandra (L.) growing in the eastern cape, South Africa. African $J$ Tradit Complement Altern Med 2015; 12(3): 1-8. https://doi.org/10.4314/ajtcam.v12i3.1

[25] Falode JA, Obafemi TO, Akinmoladun AC, Olaleye MT, Boligon AA, Athayde ML. High-performance liquid chromatography ( HPLC) fingerprinting and comparative antioxidant propeties of rootbark and leaf extracts of Calliandra portoricensis Phytochemical Research Laboratory, Department of Industrial Pharmacy, Federal University of I 2018; 1.

[26] Ahmed D, Khan MM, Saeed R. Comparative Analysis of Phenolics, Flavonoids, and Antioxidant and Antibacteria Potential of Methanolic, Hexanic and Aqueous Extracts from 2015; 394-409. https://doi.org/10.3390/antiox4020394

[27] Rauf A, Imran M, Abu-Izneid T, lahtisham-Ul-Haq, Patel S, Pan $X$, et al. Proanthocyanidins: A comprehensive review. Biomed Pharmacother 2019; 116(May). https://doi.org/10.1016/j.biopha.2019.108999

[28] Sharifi-Rad J, Rodrigues CF, Sharopov F, Docea AO, Karaca AC, Sharifi-Rad M, et al. Diet, lifestyle and cardiovascular diseases: Linking pathophysiology to cardioprotective effects of natural bioactive compounds. Vol. 17, International Journal of Environmental Research and Public Health 2020. https://doi.org/10.3390/ijerph17072326

[29] Cos P, Bruyne T, Hermans N, Apers S, Berghe D, Vlietinck A. Proanthocyanidins in Health Care: Current and New Trends. Curr Med Chem 2012; 11(10): 1345-59. https://doi.org/10.2174/0929867043365288

[30] Poojar B, Ommurugan B, Adiga S, Thomas H, Sori RK Poojar B, et al. Methodology Used in the Study. Asian J Pharm Clin Res 2017; 7(10): 1-5. https://doi.org/10.22159/ajpcr.2017.v10i8.18923

[31] Huang HL, Fang LW, Lu SP, Chou CK, Luh TY, Lai MZ DNA-damaging reagents induce apoptosis through reactive oxygen species-dependent Fas aggregation. Oncogene 2003; 22(50): 8168-77. https://doi.org/10.1038/sj.onc. 1206979 
[32] Panche AN, Diwan AD, Chandra SR. Flavonoids: An overview. J Nutr Sci 2016; 5.

https://doi.org/10.1017/jns.2016.41

[33] Akinrinde AS, Afolayan AJ, Bradley G. Phytochemical Composition and Antioxidant Activities of Dianthus Thunbergii Hooper and Hypoxis Argentea Harv Ex Baker: Plants Used for the Management of Diabetes Mellitus in Eastern Cape, South Africa. Pharmacogn Mag [Internet] 2018; 13 (Suppl(62): 14(54): 195-202. https://doi.org/10.4103/pm.pm 15717

[34] Jamei R, Anvari D. Evaluation of Antioxidant Capacity and Phenolic Content in Ethanolic Extracts of Leaves and Flowers of Some Asteraceae Species 2018; 9: 42-9. https://doi.org/10.2174/2212798409666171023150601

[35] Altemimi A, Lakhssassi N, Baharlouei A, Watson DG. and Identification of Bioactive Compounds from Plant Extracts 2017. https://doi.org/10.3390/plants6040042

[36] A. A, Thiede B, Zidenberg-Cherr S. Nutrition and Health Info Sheet: Phytochemicals 2016.

[37] Dibal NI, Garba SH. Role of quercetin in the prevention and treatment of diseases : Mini review 2018; (11): 647-56. https://doi.org/10.21472/bjbs.051104

[38] Manach C, Williamson G, Morand C, Scalbert A, Rémésy C. Bioavailability and bioefficacy of polyphenols in humans. I. Review of 97 bioavailability studies. Am J Clin Nutr 2005; 81(1 Suppl). https://doi.org/10.1093/ajcn/81.1.230S

[39] Boyer J, Liu RH. Apple phytochemicals and their health benefits. Nutr J 2004; 3: 1-45. https://doi.org/10.1186/1475-2891-3-5

[40] Gallus S, Talamini R, Bosetti C, Negri E, Montella M, Franceschi S, et al. Pizza consumption and the risk of breast, ovarian and prostate cancer. Eur J Cancer Prev 2006; 15(1): 74-6. https://doi.org/10.1097/01.cej.0000186632.04625.f6

[41] Gillespie L. Use of saponins to replace egg whites in alcoholic and non-alcoholic beverages 2016; 1(19).

[42] Jorat MV, Tabrizi R, Mirhosseini N, Lankarani KB, Akbari M, Heydari ST, et al. The effects of coenzyme Q10 supplementation on lipid profiles among patients with coronary artery disease: A systematic review and metaanalysis of randomized controlled trials. Lipids Health Dis 2018; 17(1): 1-9. https://doi.org/10.1186/s12944-018-0876-4

[43] Nayak B, Liu RH, Tang J. Effect of Processing on Phenolic Antioxidants of Fruits, Vegetables, and Grains-A Review. Crit Rev Food Sci Nutr 2015; 55(7): 887-919. https://doi.org/10.1080/10408398.2011.654142

[44] Al-laith AA, Alkhuzai J, Freije A. Assessment of antioxidant activities of three wild medicinal plants from Bahrain. Arab J Chem [Internet] 2019; 12(8): 2365-71. https://doi.org/10.1016/j.arabjc.2015.03.004

[45] Sandeepa KH, Harsha1 TS, Prashanth M, Kekuda TRP Raghavendra HL. In vitro antioxidant activity of Anaphalis lawii ( Hook . f) Gamble and Helichrysum buddleioides DC a comparative study. J Biosci Agric Res 2017; 12(March). https://doi.org/10.18801/jbar.120217.130

[46] Idamokoro EM, Masika PJ, Muchenje V. A Report on the In vitro Antioxidant Properties of Vachellia karroo Leaf Extract: A Plant Widely Grazed by Goats in the Central Eastern Cape of South Africa 2017. https://doi.org/10.3390/su9020164

[47] Pmw B, Krishnan K, Jp A, Pmw B, Krishnan K, Jp A. Nitric oxide donors (nitrates), L-arginine, or nitric oxide synthase inhibitors for acute stroke (Review) 2017.

\section{DOI: https://doi.org/10.29169/1927-5951.2020.10.06.3}

(C) 2020 Aladejana et al.; Licensee SET Publisher.

This is an open access article licensed under the terms of the Creative Commons Attribution Non-Commercial License (http://creativecommons.org/licenses/by-nc/3.0/) which permits unrestricted, non-commercial use, distribution and reproduction in any medium, provided the work is properly cited. 